\title{
Two new species of the millipede genus Hyleoglomeris Verhoeff, 1910 from near Java, Indonesia (Diplopoda: Glomeridae)
}

\author{
Ава новых вида диплопод рода Hyleoglomeris Verhoeff, 1910, \\ найденных побцизости от острова Ява (Индонезия) \\ (Diplopoda: Glomeridae)
}

\author{
S.I. Golovatch ${ }^{1} \&$ J.-J. Geoffroy ${ }^{2}$ \\ С.И. Головач ${ }^{1}$, ЖК.-ЖК. Жоффруа ${ }^{2}$
}

\begin{abstract}
${ }^{1}$ Institute for Problems of Ecology and Evolution, Russian Academy of Sciences, Leninsky pr. 33, Moscow 119071, Russia.
${ }^{1}$ Институт проблем экологии и эволюции РАН, Ленинский пр. 33, Москва 119071 Россия.

${ }^{2}$ Muséum national d'Histoire naturelle, Département Ecologie \& Gestion de la Biodiversité, UMR 7204 CERSP du CNRS, Equipe EVOLTRAIT, 4, avenue du Petit Château, F-91800 Brunoy, France.
\end{abstract}

KEY WORDS: Diplopoda, Hyleoglomeris, new species, Nusakambangan Island, Java, Indonesia. КЛЮЧЕВЫЕ СЛОВА: Diplopoda, Hyleoglomeris, новый вид, остров Нусакамбанган, Ява, Индонезия.

ABSTRACT. Two new pigmented species of the large, basically warm temperate to tropical Eurasian genus Hyleoglomeris are described from Nusakambangan Island, a small island off the southern coast of Java, Indonesia: H. contrasta sp.n. and H. fusca sp.n. Both differ from congeners, including $H$. jacobsoni (Silvestri, 1917), the sole species of the genus hitherto known to occur in Java, by their colour patterns and a few structural details of male legs 17-19.

РЕЗЮМЕ. Описаны два новых пигментированных вида большого, в основном теплотемператного до тропического евразийского рода Hyleoglomeris с острова Нусакамбанган близ южного побережья острова Ява (Индонезия): H. contrasta sp.n. и $H$. fusca sp.n. Оба отличаются от других видов рода, включая H. jacobsoni (Silvestri, 1917), единственного другого представителя рода, пока известного с Явы, своей окраской и некоторыми деталями строения ног 17-19 самца.

\section{Introduction}

The millipede genus Hyleoglomeris Verhoeff, 1910 is one of the largest and certainly the most widespread in the entire order Glomerida. At the moment, this genus contains 89 nominate species, ranging from the Balkans in the West to Japan in the East, and the Sunda Archipelago (Sulawesi) in the Southeast [Golovatch et al., 2006, 2012].

Only one species has hitherto been known from Java: H. jacobsoni (Silvestri, 1917), first described as Apiomeris (Hyleoglomeris) jacobsoni Silvestri, 1917, from Java (Nongkodjadjar) [Silvestri 1917], and later reported from several Lesser Sunda islands: Bali (Gitgit), Sumbawa (Batoe Doelang) and Flores (Geli Moetoe) [Attems, 1930]. Based solely on 3- rather than 4segmented male telopodites 17 as illustrated by Attems [1930], Verhoeff [1936] established Sundameris to only incorporate $H$. jacobsoni. The conspecificity of Attems' samples with type material is still to be verified [cf. Verhoeff 1936; Golovatch et al., 2006]. A subgeneric division of Hyleoglomeris has since been abandoned, instead several species groups have been delimited [Golovatch et al., 2006, 2012].

Prompted by the discovery of two new congeners from Nusakambangan, an island off the southern coast of Java, below we provide their descriptions. The holotypes will be deposited in the collection of the Museum Zoologicum Bogoriense, Cibinong, Indonesia (MZB), while a few paratypes will be shared between the collections of the Muséum national d'Histoire naturelle, Paris, France (MNHN) and Zoological Museum, University of Moscow, Russia (ZMUM).

Taxonomic part

Hyleoglomeris contrasta $\mathbf{s p . n .}$ Figs $1 \mathrm{~A}-\mathrm{C} \& 2$.

HOLOTYPE O’ (MZB), Indonesia, Java, Jawa Tengah, Nusakambangan Isle, Cilacap, Cilacap South, near Cave Goa Batu Gantung, kebun, litter, dead wood, 18.02.2011, leg. L. Deharveng \& Dito (JAVA-NK24)

PARATYPES: 3 오 (MZB), 2 우 (MNHN CC 181), 1 우 (ZMUM), same locality, together with holotype.

NAME. To emphasize the contrasting colour pattern.

DIAGNOSIS. Differs from congeners primarily in the unusual colour pattern, in which the head and terga 


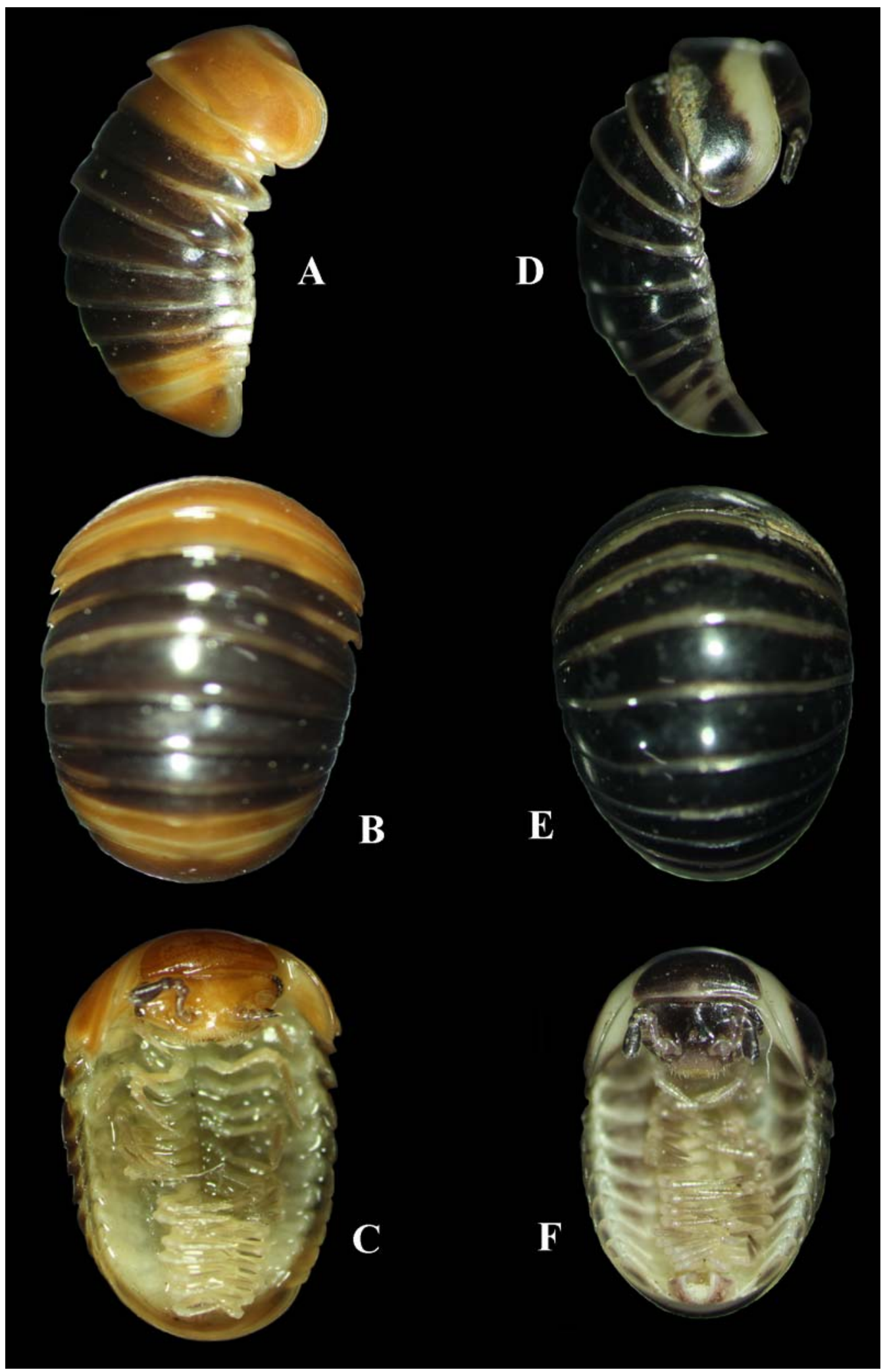

Fig. 1. Habitus of Hyleoglomeris contrasta sp.n.,, paratype (A-C), and of Hyleoglomeris fusca sp.n.,, paratype (D-F), lateral, dorsal and ventral views, respectively. Photographed not to scale.

Рис. 1. Габитусы Hyleoglomeris contrasta sp.n., паратип + (A-C), и Hyleoglomeris fusca sp.n., паратип + (D-F), соответственно сбоку, сверху и снизу. Сфотографировано без масштаба. 


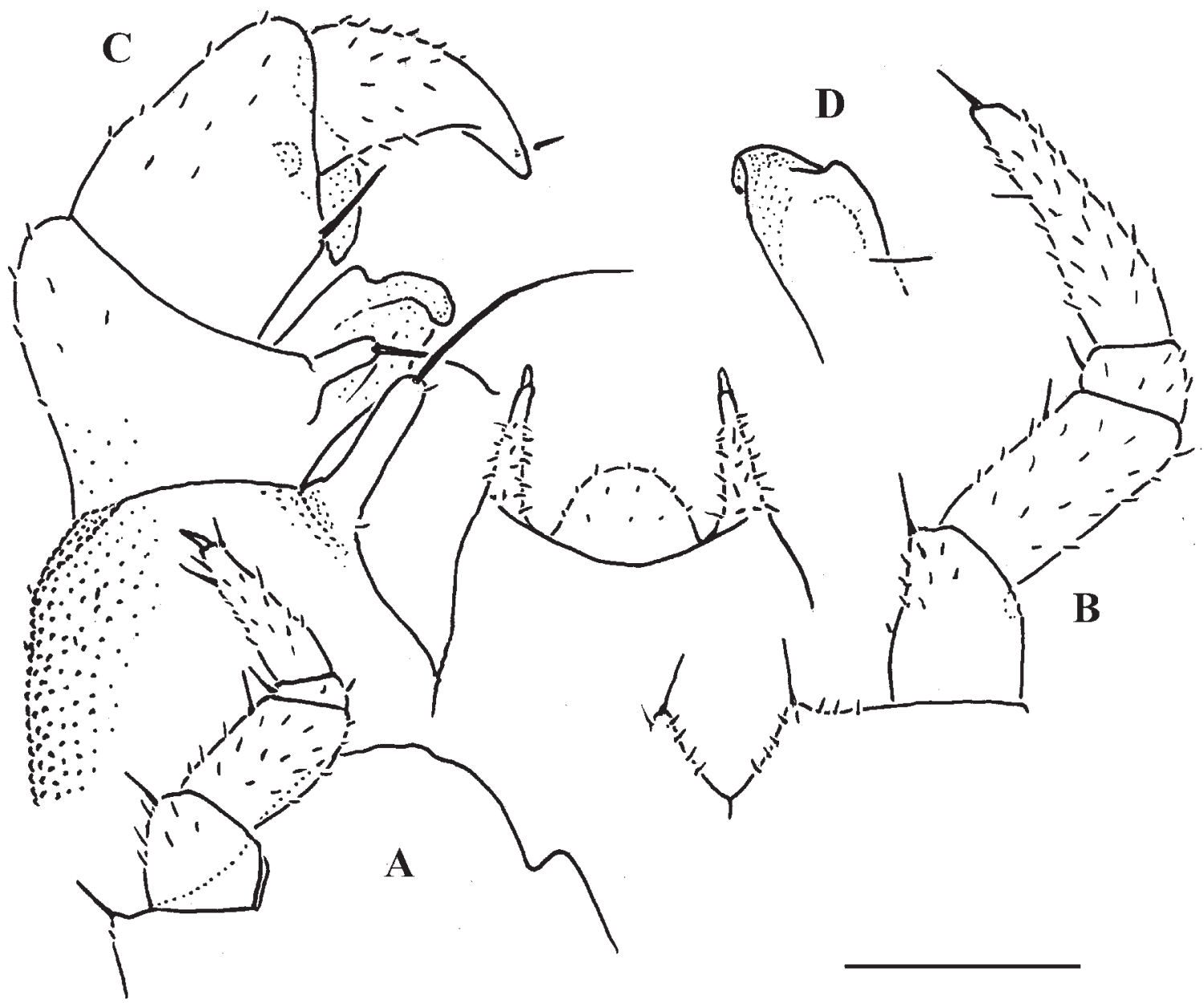

Fig. 2. Hyleoglomeris contrasta sp.n., holotype: A — leg 17, front view; B — leg 18, front view; C - left half of telopod, front view; D - caudomedial femoral process, caudal view. Scale bar: $0.2 \mathrm{~mm}$.

Рис. 2. Hyleoglomeris contrasta sp.n., голотип: А - нога 17, спереди; В - нога 18, спереди; С - левая половина телопода, спереди; D - заднемедиальный отросток бедра, сзади. Масштаб 0,2 мм.

$1-3,10,11$, as well as the pygidium are contrasting orange or light red-brown while terga 4-9 are blackish (Fig. 1A-C).

DESCRIPTION. Length ca 6.0 (holotype) or 6.5 $8.0 \mathrm{~mm}$ (paratypes), width 2.9 (holotype) or 3.0-3.8 $\mathrm{mm}$ (paratypes). Coloration very vivid, colour pattern strongly contrasting. Head, collum, thoracic shield and terga 3,10 and 11, as well as pygidium light marbled orange to light red-brown, strongly contrasting to darker ocelli, antennae and terga 4-9 (Fig. 1A-C). Ocelli blackish. Antennae increasingly infuscate distad (basal antennomeres reddish-brown, $5^{\text {th }}$ to $7^{\text {th }}$ dark red-brown to blackish, Fig. 1C). Terga 4-9 blackish, with very vague, large, transversely oval, marbled, lateral spots lying faraway from both midline and the usual lateral light margin. Terga 2, 3, 10 and 11 also with similar, but light yellowish, marbled, oblong, lateral spots or markings. Pygidium devoid of spots, only sometimes slightly infuscate (brownish) at lateral corners. Venter and legs yellowish (Fig. 1C).
Ocelli $6+1$ or 7+1, translucid, convex; Tömösváry’s organ transverse-oval, only slightly wider than long. Antennomere $6 \mathrm{ca}$ 1.6-1.7 times as long as high.

Collum with two transverse striae. Tergum 2 (=thoracic shield) with a narrow hyposchism not reaching behind the caudal tergal margin; 9 or 10 superficial transverse striae, five starting below schism, 1 or 2 level to, all others above schism while 2 or 3 (never last one from below) crossing the dorsum. $\sigma^{7}$ anal shield regularly rounded at caudal margin.

$\mathrm{O}^{7}$ leg 17 (Fig. 2A) with a rather high and irregularly shaped outer coxal lobe; telopodite 4-segmented.

$\sigma^{7}$ leg 18 (Fig. 2B) with an arch-shaped syncoxital notch; telopodite 4-segmented.

Telopods (Fig. 2C, D) with a rather high, nearly semi-circular, sparsely setose, central syncoxital lobe flanked by two setose horns, each latter crowned with a minute, elongate lobule devoid of adjacent structures (Fig. 2C). Prefemur and, to a far lesser extent, femur micropapillate laterally. Caudomedial femoral process 


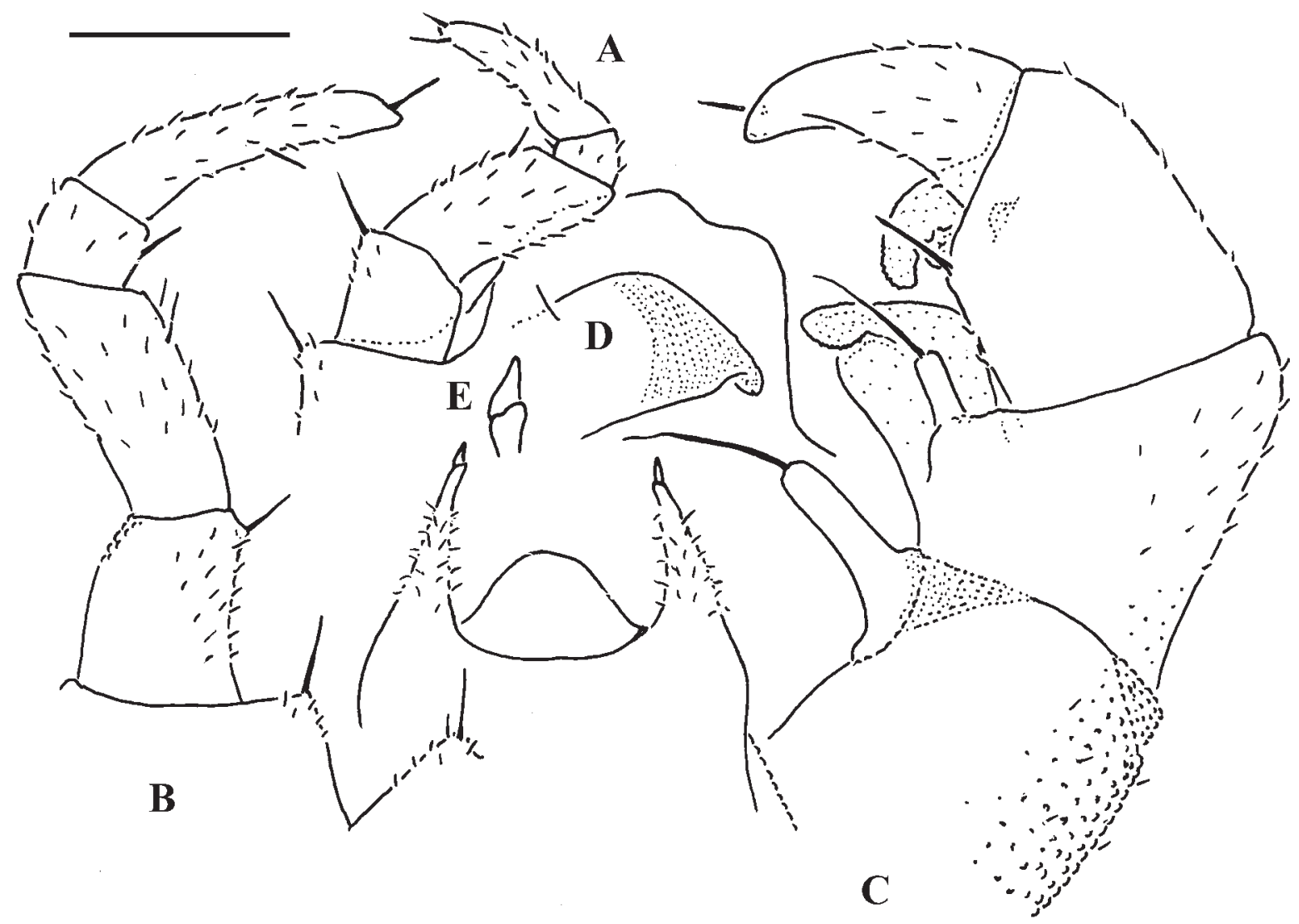

Fig. 3. Hyleoglomeris fusca sp.n., holotype: A — leg 17, front view; B - leg 18, front view; C - right half of telopod, front view; D - caudomedial femoral process, caudal view; E - tip of telopod syncoxital horn. Scale bar: $0.2 \mathrm{~mm}$.

Pис. 3. Hyleoglomeris fusca sp.n., голотип: А - нога 17, спереди; В - нога 18, спереди; С - правая половина телопода, спереди; D - заднемедиальный отросток бедра, сзади; Е — вершина рога синкоксита телопод. Масштаб 0,2 мм.

(Fig. 2D) prominent, directed distomedially at ca $100^{\circ}$ to femur, mostly strongly chitinized, apically with a small membranous sac, distolaterally with a small, conspicuous lobe. Caudomedial process of tibia evident, sac-shaped, membranous, with an evident glabrous tubercle at base. Tarsus rather slightly sigmoid, subacuminate apically.

\section{Hyleoglomeris fusca sp.n.}

Figs 1D-F \& 3.

HOLOTYPE $\sigma^{7}$ (MZB), Indonesia, Java, Jawa Tengah, Nusakambangan Isle, Ujung Galang, Klaces, near Goa Maria, forest, litter, sifting \& Berlese extraction, 22.02.2011, leg. Sofyan \& A. Bedos (JAVA-NK58).

PARATYPE: 1 (MZB), same locality, together with holotype.

NAME. To emphasize the animal's prevailing dark coloration.

DIAGNOSIS. This new species seems to be particularly similar to $H$. contrasta sp.n., but differs in the completely dark antennae, head, collum, terga 2-10 and anal shield (Fig. 1D-F). The overall dark coloration agrees nearly fully with that described for $H$. jacobsoni, but the caudal margins of the terga, as well as the venter and legs in the latter species are orange [Silvestri, 1917].
DESCRIPTION. Length ca 6.0 (holotype) or 7.0 $\mathrm{mm}$ (paratype), width 3.4 (holotype) or $3.3 \mathrm{~mm}$ (paratype). Coloration nearly entirely dark brown to blackish, a few basal antennomeres sometimes a little lighter, brownish. Tergum 2 in front third entirely crossed by a wide white band (Fig. 1D \& F). Tergum 11 mostly white as well, only its lateralmost parts blackish (Fig. 1D). Pleurites brown, legs very light brown (Fig. 1F).

Ocelli $5+1$ or $6+1$, translucid, strongly convex. Antennomere 6 ca $1.5-1.6$ times as long as high.

Tergum 2 with 9 or 10 transverse striae, 5 or 6 starting below, one level to, the remaining striae above schism, 4 or 5 crossing the dorsum.

$\sigma^{7}$ leg 17 (Fig. 3A) with a high and rather irregularly shaped outer coxal lobe; telopodite 4-segmented.

$\sigma^{7}$ leg 18 (Fig. 3B) with a V-shaped syncoxital notch; telopodite 4-segmented.

Telopods (Fig. 3C-E) with a rather high, regularly rounded, sparsely setose, central syncoxital lobe flanked by two setose horns, each latter crowned by a minute, elongate lobule devoid of any adjacent structures (Fig. 3E). Prefemur and, to a far lesser extent, femur micropapillate laterally. Caudomedial femoral process prominent, crowned with a membranous sac, but devoid 
of any chitinized lobe (Fig. 3D). Caudomedial process of tibia very evident, membranous; tibial tubercle on caudal face low and glabrous. Tarsus rather slightly sigmoid, subacuminate apically.

\section{Remarks}

Both of the new species seem to be quite similar to each other, especially as regards the structure of $\sigma^{7}$ legs 17-19. This is also confirmed by their provenance from the same small island. Both differ markedly not only from each other, but also from $H$. jacobsoni, the latter species described as being uniformly dark, devoid of a pattern, but having the caudal parts of the terga, as well as the venter and legs orange [Silvestri, 1917]. Certain differences between these three species are also observed in the structure of $\sigma^{7}$ legs 17-19, e.g. the shapes of the telopod syncoxital lobe and caudofemoral process.

ACKNOWLEDGEMENTS. Collecting on Nusakambangan Island and the organization of a field trip of Louis Deharveng and Anne Bedos (both MNHN, Paris, France) were made possible thanks to FFI (Fauna Flora International-Indonesia). The help of Holcim, who facilitated their access to the karst of the island, is greatly acknowledged.
The LIPI-MZB provided the permits to study the collected material. Pictures were taken and prepared for publication by Weixin Liu (South China Agricultural University, Guangzhou City, Guangdong Province, China). Special thanks go to the MNHN administration for financing the first author's stay in Paris in March and April 2012.

\section{References}

Attems C. 1930. Myriopoden der Kleinen Sunda-Inseln gesammelt von der Expedition Dr Rensch // Mitteilungen aus dem Zoologischen Museum Berlin. Bd.16. S.117-184.

Golovatch S.I., Geoffroy J.-J., Mauriès J.-P. 2006. Review of the millipede genus Hyleoglomeris Verhoeff, 1910 (Diplopoda, Glomerida, Glomeridae), with descriptions of new species from caves in Southeast Asia // Zoosystema. Vol.28. No.4. P.887915.

Golovatch S.I., Weixin L., Geoffroy J.-J. 2012. Review of the millipede genus Hyleoglomeris Verhoeff, 1910 in China, with descriptions of new species (Diplopoda, Glomerida, Glomeridae) // Zootaxa. No.3358. P.1-27.

Silvestri F. 1917. Contributions to a knowledge of the Oriental Diplopoda Oniscomorpha. 1. The family Glomeridae // Records of the Indian Museum. Vol.13. P.103-151.

Verhoeff K.W. 1936. Ueber Diplopoden aus Japan gesammelt von Herrn Y. Takakuwa // Transactions of the Sapporo Natural History Society. Vol.14. No.3. P.148-172.

Responsible editor K.G. Mikhailov 